\title{
The investigation of distribution of hereditary alpha-thalassemia mutations in Isparta reservoir
}

\section{Isparta ve Çevresinde Alfa-Talasemi Kalıtsal Mutasyonlarının Dağılımının Araștırılmảsı}

Recep Sütçü ${ }^{1}$, Firdevs Aylak ${ }^{1}$, Havva Koçak ${ }^{1}$, Tansu Sipahi², Hüseyin Vural ${ }^{1}$, Namık Delibaș ${ }^{1}$

${ }^{1}$ SDÜ Tıp Fakültesi Tıbbi Biyokimya AD,

Ufuk Üniversitesi Tıp Fakültesi Pediatrik Hematoloji Bilim Dalı, Isparta, Türkiye

Eur J Basic Med Sci 2011;1 (1):28-32

Geliș Tarihi (Received): 21-12-2010

Kabul Tarihi (Accepted):17-01-2011

Yazıșma Adresi (Correspondence):

Doç. Dr. Recep SÜTÇÜ

Süleyman Demirel Üniversitesi Tıp Fakültesi, Tıbbi Biyokimya AD Isparta

Tel: +902462112074

E-posta:rsutcu@hotmail.com

\begin{abstract}
Thalassemia is an autosomal recessive disease characterized by the absence or decreased production of the alpha globin chain. The aim of this study was to make the valuable contributions to the map of thalassemia in Turkey and to help the clinicians who plan to cure the patients in our region. Among the individuals who applied to Hematology Department of SDU Medical Faculty with a suspected alpha thalassemia mutation, 25 were selected for present study. Mutations in alpha globin gene were detected by using a-globin StripAssayTM commercial kit. The principle of the assay is based on reverse hybridization. As a result, the most common alpha thalassemi mutations were MED double gene deletion, -20.5 kb single gene deletion, -3.7 single gene deletion and a2IVS 1-5 nt respectively, in Isparta reservoir.
\end{abstract}

Key Words: Alpha globin chain, deletions, alpha thalassemia 


\section{ÖZET}

Alfa talasemi, alfa globin zinciri üretiminde azalma ya da tamamen kaybolma ile karakterize otozomal resesif bir hastalıktır. Çalıșmamızdaki bu veriler tanı koyma ve tedaviyi planlamada klinisyene yardımcı olabilir ve ülkemizin talasemi haritasının belirlenmesine katkıda bulunabilir. Bu çalıșmaya dahil edilen 25 kiși, SDÜ hastanesi çocuk hematoloji polikliniğine bașvuran alfa talasemi mutasyonu araștırılan hastalardan seçildi. Alfa globin genindeki mutasyonların analizi ViennaLab a-globin StripAssayTM kiti kullanılarak gerçekleștirildi. Yöntemin prensibi reverse hibridizasyon tekniğine dayalıydı. Elde ettiğimiz sonuçlara göre, Isparta ve çevresinde en yaygın görülen alfa talasemi mutasyonu MED double gen delesyonu olarak bulundu. Bunu sirasiyla $-20.5 \mathrm{~kb}$ single gen delesyonu, -3.7 single gen delesyonu ve a2IVS 1-5 nt mutasyonu takip etti.

Anahtar Kelimeler: Alfa globin zinciri, delesyonlar, alfa talasemi

\section{Gíriş}

Alfa globin polipeptid zincirlerinin azalması ya da tamamen yokluğu alfa talaseminin nedenidir. Bu gen defektinin neden olduğu hemoglobin bozukluğu, dünyada șu anda bilinen en önemli hemoglobin bozukluğudur $(1,2)$. Dünya nüfusunun \%5'ini etkileyen ve tüm tek gen bozukluklarının muhtemelen en yaygın olanıdır (3). Alfa talasemi sıklığı ve mutasyon dağılımının bilinmesi prenatal tanı ve hasta bakımı için daha iyi danıșmanlık yapılmasını sağlar $(4,5)$. Alfa talasemi otozomal resesif geçiş göstermekte ve hastalığın șiddeti asemptomatik tașıyıcıdan in utero ölüme kadar değișebilen bir dağılım göstermektedir (3). Hemoglobin molekülünün yapısında yer alan alfa globin zincirlerinin sentezinden sorumlu olan alfa gen kümesi 16 numaralı kromozom üzerindedir. Normalde her bir 16 numaralı homolog kromozomda ikișer tane olmak üzere toplam dört tane alfa globin geni vardır (aa/aa). Aynı kromozom üzerindeki alfa genlerine 5' - 3'doğrultusunda, a2 ve a1 isimleri verilir. Bu genler yapısal olarak birbirinin kopyasıdır (duplikasyon). Bu genler üzerinde meydana gelen delesyonlar veya nokta mutasyonları sonucu globin zinciri sentezi azalmakta veya tamamen yok olmaktadır (6).

Alfa talasemiler delesyonel ve delesyonel olmayan olmak üzere iki gruba ayrılır. Gen delesyonları alfa talasemide en sık rastlanılan hastalık sebebidir. Delesyonların genișliği önemlidir ve klinik fenotipi etkilemektedir. Alfa talasemide en az 40 tane farklı delesyon bulunmuștur. Delesyonel olmayan mutasyonlar, delesyonel mutasyon- lardan daha hafif bir fenotipe sahiptir (3). Önceleri alfa talasemi mutasyonlarının fenotipi doğrudan etkilenmiș alfa globin gen sayısı ile ilișkilendirilmiștir. Bir gen delesyonu sessiz taşıyıcı (alfa talasemi-2), iki gen delesyonu alfa talasemi taşıyıcı (alfa talasei-1); üç gen delesyonu Hemoglobin $\mathrm{H}$ ve dört gen delesyonu hidrops fötalis olarak sonuçlanmıștır. Bugün ise alfa talasemi sendromunun fenotipi ve genotipinin daha kompleks ve değișken olduğu fark edilmiștir. Fenotip çeșitleri sadece etkilenmiș alfa gen sayısına değil alfa talasemi mutasyon tipiyle de bağlantılıdır. Geniș delesyonlar, delesyonel olmayan mutasyonlar, düzenleyici bölgede değișim ve unstabil mutasyonların hepsi fenotipin şiddetini arttırıcı yönde etki göstermektedir. (3).

\section{GEREÇ VE YÖNTEM}

Süleyman Demirel Üniversitesi Hastanesi çocuk hematoloji polikliniğine başvuran alfa talasemi mutasyonu araștırılan 25 hasta çalıșmaya alındı. Hastalardan $2 \mathrm{~mL}$ venöz kan örneği EDTA içeren tüplere alındı. Bu amaçla alınan kan örneklerinden Gen polimorfizmini tespit etmek için alınan kan örneklerinden İnvitek marka İnvisorb Spin Blood Mini Kit (Germany) kullanılarak tam kandan DNA izolasyonu yapıldı. Alfa globin gen bölgelerine ait biotin işaretli primerler kullanılarak PCR multipleks yöntemi ile in vitro amplifikasyon yapıldı. Amplifikasyon ürünleri Alfa globin genindeki mutasyonlar reverse hibridizasyon prensibine dayalı ViennaLab a-globin StripAssayTM ticari kiti (ViennaLab Labordiagnostica, Austria) kullanilarak tespit edildi.

\section{BULGULAR}

Süleyman Demirel Üniversitesi Tıp Fakültesi Hastanesi Çocuk Hematolojisi polikliniğine başvuran ve alfa talasemi mutasyonu araștırılan 25 hastadan 9 tanesinin Heterozigot formunda allel taşıdığı tespit edildi. Bu hastaların 5 tanesinde MED double gen delesyonu (heterozigot mutasyon), 2 tanesinde $-20.5 \mathrm{~kb}$ single gen delesyonu (heterozigot mutasyon), 1 tanesinde azIVS 1-5 nt delesyonu (heterozigot) ve diğer 1 tanesinde -3.7 single gen delesyonu (heterozigot) tespit edildi. Bu 25 hastadan 16 tanesinde herhangi bir mutasyona rastlanmamıștır. 


\section{TARTIŞMA}

Talasemi, Hb'nin bir alt ünitesi olan globin zincirlerinin sentezinin yokluğu veya azalmasıly karakterize genetik bozuklukların bir grubudur. Akdeniz ülkeleri, Ortadoğu, Güney Asya, Sri Lanka, Maldivler, Güneydoğu Asya, Malezya, Güney Çin ve Tayvan'ı kapsayan bölgelerde yaygın olarak görülmektedir (7). Hemoglobinopatilerin önlenmesinde en etkin yöntemler tașıyıcıların tespit edilmesi, tașıyıcılara genetik danıșma verilmesi ve prenatal tanı metotlarının kullanılması ile hemoglobinopatili bebek doğumunun önlenmesini kapsamaktadır (8).

Alfa globin gen mutasyonlarının ortaya çıkarılması, özellikle prenatal dönemdeki tedavi stratejilerinin belirlenmesine büyük katkı sağlayacaktır. Her ne kadar alfa globin geninin tamamında DNA dizinlemesiyle bilinmeyen mutasyonların tespiti uygulanabilir olsa da, çok pahalı olduğundan özellikle gelișmekte olan ülkelerde bu teknoloji rutin olarak uygulanamamaktadır. Bunun için dizi analizinden önce ucuz, hızı bir moleküler tespit metoduna ihtiyaç vardır (7). Son yıllarda piyasaya çıkarılan ve șu anda üçüncü nesli geliștirilmiş olan alfa globin Strip Assay (ViennaLab) adlı kit Türkiye'de talasemi tanısını büyük oranda kolaylaștırmıștır. Bu test PCR ile çoğaltılmıș DNA ürünlerinin mutasyona özgü oligonükleotid problarıla hibritleșmesi prensibi üzerine kurulmuştur (9).

Talasemiler moleküler düzeyde oldukça heterojen olup, alfa talasemili hastalarda, alfa globin geninin 40'dan fazla farklı mutasyonu tespit edilmiștir. Önemli olarak, dünyada yüksek sıklığa sahip popülasyonların her birinin özellikle belli bir bölgede sadece birkaç yaygın mutasyonu taşıdığı görülmektedir, bunun yanında nadir olanlarda görülebilir. 40 mutasyonun tümünün her toplumda görülmemesi ve mutasyonların etnik gruplara özgün olması, bu geniș moleküler çeșitliliği biraz basite indirgeyen bir faktör olmuştur (9).

Dünyada ve Türkiye'de alfa talasemi mutasyonlarının sıklığı ve dağııımı üzerine çok sayıda çalıșma yapılmıștır. Çukurova bölgesinde Çürük MA. ve ark.'nın yaptıkları bir çalıșmada, her iki alfa globin genini içine alan üç büyük delesyon (--/aa) ve tek alfa genini kapsayan (-a/aa) iki küçük delesyon belirlenmiștir. Delesyonel olmayan alfa talasemi mutasyonlarından a2 geni üzerinde iki farklı PolyA mutasyonu ve bir tane de 5 nükleotidlik $(-5 n t)$ küçük delesyon ile a1 geni üzerindeki nokta mutasyonu sonucu meydana gelen $\mathrm{Hb}$ Adana, $\mathrm{HbH}$ hastaları ve onların aile çalıșmaları sırasında tespit edilmiștir(10). Adana ve çevresinde yenidoğan bebeklerden kordon kanı alınarak yapılan tarama çalıșmasında alfa talasemi tașıyıcı oranı \%2.9 olarak rapor edilmiștir (11). Alfa talasemi konusundaki genotip çalıșmaları, $\mathrm{HbH}$ hastaları ve aileleri üzerinde yapılmıș olup, Akdeniz ülkelerinde görülen beș farklı gen delesyonu belirlenmiștir $(12,13,14,15)$. Bunlardan üç tanesi $(26.5 \mathrm{~kb}, 20.5 \mathrm{~kb}$ ve $17.4 \mathrm{~kb})$ aynı allel üzerindeki a2 ve a1 genlerini içine alan ağır alfa talasemi delesyonları (a-thal-1: --/aa), diğerleri (-3.7 kb ve -4.2 $\mathrm{kb})$ ise sadece bir alfa genini içine alan ( $\alpha$-thal-2:- $\alpha / \mathrm{a \alpha}$ ) sessiz alfa talasemi delesyonlarıdır. Çukurova bölgesinde alfa talasemi mutasyonlarından $-26.5 \mathrm{~kb}$ (Med II) ve -4.2 kb delesyonları ender olarak 20.5 kb, 17.4 kb ve 3.7 kb lik delesyonlar ise yaygın olarak görülmüștür $(13,14,15,16)$. Delesyonel olmayan alfa talasemi mutasyonlarından PolyA kuyruğu üzerinde bulunan PA1: AATAAA-AATAAG ilk kez Arap ülkelerinde yașayan hastalarda $(\mathrm{HbH})$ karekterize edilmiștir (17). PA2: AATAAA-AATGAA mutasyonu ise ilk kez Adana'da yaşayan $\mathrm{HbH}$ hastalarının analizi sırasında Med II delesyonu ile birlikte bulunmuștur (14). Alfa-2 genindeki IVS1'in donör kısmında bulunan 5 nükleotidlik delesyon (-5 nt: -TGAGG) da diğer bir $\mathrm{HbH}$ hastasında Med II delesyonu ile kombine görülmüștür. Bu üç farklı nondelesyonel alfa talasemi mutasyonu komşu ülkelerde de $\mathrm{HbH}$ hastalığı ile birlikte rapor edilmiștir $(13,14,18,19)$.

Alfa globin genlerinin üzerinde bulunan ve aminoasit değişimi ile meydana gelen dayanıksız $\mathrm{Hb}$ varyanlarının da alfa talasemiye neden olduğu tespit edilmiștir. -a3.7 tek gen delesyonu dünya çapında bir dağılıma sahip olup, Afrika, Akdeniz ve Asya popülasyonunda en dominant mutasyon olarak karşımıza çıkmatadır (20). Doğu Malezya'da Jin-AiMary Anne Tan ve ark'nın yaptıkları bir çalıșma ile single a-globin gen delesyonunun (-a3.7) yaygın olduğu gösterilmiștir (20).

İran'da Kerman vilayetin'de Nasrollah Saleh-Gohari ve ark'nın yaptıkları bir çalıșmada da a-globin genine ait mutasyonlar arasinda -a3.7mutasyonunun en yaygın mutasyon olduğu gösterilmiștir. Bunu takiben a-globin gene defektlerinden sirasiyla kodon 19 (a2) ve $-5 \mathrm{nt} /$ aa (a2) mutasyonlarının sıklıkla görüldüğü bildirilmiștir (21).

Hadavi ve ark (22) güney ve güneydoğu İranda sirasiyla -a3.7 ve polyadenylation signal site 2 (poly A2) (a2) mutasyonlarının en sık görülen a-globin gen mutasyonları olduğunu bildirmişlerdir (22). - -a3.7 mutasyonu İran'da en yaygın a-globin gen mutasyonu olarak 
önceden bildirilmiştir. Alfa talasemi sıklığı ve mutasyon spektrumunun bilinmesi prenatal tanı ve takip için daha iyi bir danıșmanlık sağlar. Kerman vilayetinde 566 bireyin incelenen kromozomlarında 8 farklı mutasyon bulundu. -a3.7 mutasyonu en yaygin mutasyondu. Bu mutasyonların büyük çoğunluğu heterozigot durumda bulundu (-a3.7/aa). ikinci ve üçüncü sırada en sık görülen a-globin gen defekti sırasıyla kodon 19 (5.7\%) ve IVS-I, $-5 \mathrm{nt}(4.2 \%)$ nokta mutasyonlarıydı. Bu iki mutasyon homozigot ve heterozigot durumda da bulundu. Mutasyona uğramış allellerin yaklaşık \%3.7'si -a4.2 : $\% 1.8$ heterozigot ve \%0.35 homozigot durumdaydı. Geri kalan mutasyonlar kodon 142/aa (a2) (1.3\%), polyA2/aa (a2) $(0.5 \%)$, polyA1/aa (a2) $(0.5 \%)$ ve - -MED (0.3\%) idi. Vakaların \%4.2'sinde herhangi bir mutasyon bulunamadı (21).

Bizim çalısmamızda elde ettiğimiz sonuçlara göre, Isparta ve çevresinde en yaygın görülen alfa talasemi mutasyonu MED double gen delesyonu olarak bulundu. Bunu $-20.5 \mathrm{~kb}$ single gen delesyonu, -3.7 single gen delesyonu ve a2 IVS 1-5 nt mutasyonu takip etti. Çalıșmamız, Isparta ve çevresindeki mutasyonların tipini ve dağılımını belirlemek suretiyle, moleküler patolojiye göre klinik seyri, hastalığın tespit edilme așamasında tahmin edebilmesinde klinisyene yardımcı olacak, hastalığa önlem alma stratejilerine ve programlarına katkıda bulunacaktır. Ayrıca bu çalıșmadaki veriler hastaların klinik takiplerindeki verilerle birleștirilirse ve katılımcı sayısı artırılırsa hastalığın genetik geçişinin moleküler mekanizması ile fenotip arasındaki bağlantı hakkında çok daha yararlı bilgiler elde edileceğini düșünmekteyiz. Türkiye'nin alfa talasemi mutasyon haritasına da katkısı olacaktır. Genetik danıșmanlık esnasında moleküler patolojinin bilinmesi sayesinde kişiye daha açık ve güvenilir bilgiler verilebilecek dolayısıyla çocuk sahibi olma kararlarında alınabilecek erken önlemlerle gerek tıbbi abortusların uygulanma gerekliliği gerekse hasta çocuk doğma riski azaltılacaktır.

\section{KAYNAKLAR}

1. Chong SS, Boehm CD, Higgs DR, Cutting GR. Single-tube multiplex-PCR screen for common deletional determinants of a-thalassemia. Blood. 2000; 95: 360-362.

2. Kan YW. Molecular pathology of a-thalassemia. Ann NY Acad Sci. 1985;445: 28-36.

3. Vichinsky E. Complexity of alpha thalassemia: growing health problem with new approaches to screening, diagnosis, and therapy. Ann N Y Acad Sci. 2010; 1202: 180-187.
4. Harteveld CL, Refaldi C, Cassinerio E, Cappellini MD, Giordano $P C$. Segmental duplications involving the a-globin gene cluster are causing B-thalassemia intermedia phenotypes in B-thalassemia heterozygous patients. Blood Cells Mol Dis. 2008; 40: 312-316.

5. Giordano PC, Bakker-Verwij M, Harteveld CL. Frequency of a-globin gene triplications and their interaction with B-thalassemia mutations. Hemoglobin. 2009; 33: 124-131.

6. Higgs DR. Alpha thalassemia: An Overview, Ed. Stuart Roath, in Current Views on Thalassemia. Harwood Acedemic Publishers, Switzerland. 1992: 31-40.

7. Chinchang W, Viprakasit V, Pung-amritt P, Tanphaichitr $V S$, Yenchitsomanus $P$. Molecular analysis of unknown beta globin gene mutations using polymerase chain reactionsingle strand conformation polymorphism (PCR-SSCP) technique and its application in Thai families with beta thalassemias and beta globin variants. Clin Biochem. 2005; 38: 987-996.

8. Gümrük F. Hemoglobinopatilerin Tanı ve Tedavisinde Yenilikler. Türk Hematoloji Dernegi 9. mezuniyet sonrası egitim kursu 2006; 62-64.

9. Basak AN. Talasemi Moleküler Genetigi. Türk Hematoloji Dernegi Temel Moleküler Hematoloji Kursu 12-13 Mart 2005; 99-106.

10. 10. Çürük MA, Genç A, Huseynova P, Zeren F, Aksoy K. Çukurova'da Alfa Talasemi Genotipleri ve HB H Hastalığı. Turkiye Klinikleri J Pediatr Sci 2007; 3: 17-23.

11. Kılınç Y, Kümi M, Gürgey A, Altay Ç. Adana bölgesinde doğan bebeklerde kordon kanı çalısması ile alfa talasemi, G6PD enzim eksikliği ve HbS sıklığının arastırılması. Doğa $\operatorname{Tr}$ Tip ve ECz D. 1986; 10: 162.

12. Huisman THJ, Carver MFH, Baysal E. A Syllabus of Thalassemia Mutations (1997). Augusta: The Sickle Cell Anemia Foundation, 1997.

13. Öner C, Gürgey A, Öner R, Balkan H, Gümrük F, Baysal $E$, et al. The molecular basis of $\mathrm{Hb} \mathrm{H}$ disease in Turkey. Hemoglobin 1997; 21: 41-51.

14. Yüregir GT, Aksoy K, Çürük MA, Dikmen N, Fei YJ, Baysal $E$, et al. $\mathrm{Hb} \mathrm{H}$ disease in a Turkish family resulting from the interaction of a deletional alfa-thalassaemia-1 and a newly discovered poly A mutation. Br J Haematol 1992; 80: 527-532.

15. Çürük MA. HbH diseases in Southern Turkey. Hemoglobin. 2007; 31: 265-271.

16. Aluouch JR, Kılınç Y, Aksoy M, Yüregir GT, Bakioglu I, Kutlar A, et al. Sickle cell anemia among Eti-Türks; haematological, clinical and genetic observations. BJ Haematol. 1986; 64: 45.

17. Thein SL, Wallace RB, Pressley L, Clegg JB, Weatherall DJ, Higgs DR. The polyadenylation site mutation in the alphaglobin gene cluster. Blood 1988; 71: 313-319.

18. Kan YW, Dozy AM, Stamatoyannopoulos G, Hadjiminas MG, Zachariades Z, Furbetta M, et al. Molecular basis of hemoglobin $\mathrm{H}$ disease in the Mediterranean population. Blood 1979; 54: 1434-1438.

19. Galanello $R$, Aru B, Dessi $C$, et al. $H b H$ disease in 
Sardinia; molecular, hematological and clinical aspects. Acta Haematol. 1992; 88: 1-6.

20. Tan JA, Lee PC, Wee YC, Tan KL, Mahali NF, George E, et al. High prevalence of alpha- and beta-thalassemia in the Kadazandusuns in East Malaysia: challenges in providing effective health care for an indigenous group. J Biomed Biotechnol. 2010;

21. Saleh-Gohari N, Khosravi-Mashizi A. Spectrum of a-globin gene mutations in the Kerman province of Iran. Hemoglobin. 2010; 34: 451-460.
22. Hadavi V, Taromachi AH, Malekpour M, Gholami B, Law HY, Almadani N, et al. Eluciding the spectrum of a-thalassemia mutations in Iran. Haematologica. 2007; 92: 992-993.

23. Saleh-Gohari N, Khosravi-Mashizi A. Spectrum of a-globin gene mutations in the Kerman province of Iran. Hemoglobin. 2010; 34: 451-460. 
